\author{
Klaudia Słowik \\ Uniwersytet Opolski \\ (D) https://orcid.org/0000-0002-8476-9591
}

\title{
Kształtowanie postawy przedsiębiorczej wśród wychowanków z rodzin zastępczych w kontekście zasady subsydiarności
}

\begin{abstract}
The article deals with the issue of developing the entrepreneurial attitude among children placed in foster care. The subject is discussed in the context of the principle of subsidiarity, especially in the social aspect. Initially, the author presents the characteristics of family and institutional foster care. Then, she describes the essence of the subsidiarity principle in social terms. What follows is an outline of the problem of entrepreneurial attitudes among young people. Next, the author proceeds to her own research within the discussed scope. The process of a foster child's entry into an adult life is an extremely difficult stage in his or her life, and it is also a challenge for the custodians/foster parents. Therefore, preparing for independence by developing the entrepreneurial attitude among young people is necessarily a longitudinal process.
\end{abstract}

Key words: foster care, social assistance, principle of subsidiarity, entrepreneurial attitude, adulthood

\section{Wprowadzenie}

Rodzina stanowi niezwykle ciekawy, ale także skomplikowany przedmiot badań. Obszar działań badawczych w tym zakresie może być podejmowany z wielorakich perspektyw: kulturowych, społecznych, pedagogicznych, psychologicznych, czy też prawnych. W niniejszym artykule chciałabym podjąć analizę systemu rodzinnej pieczy zastępczej wobec kształtowania postawy przedsiębiorczej rozumianej jako rozwój wszelkich funkcji prospołecznych, socjalizujących. Zadaniem rodziny zastępczej jest bowiem przekazanie odpowiednich społecznych wzorców zacho- 
wań, aby wychowankowie umieszczeni w rodzinnej pieczy zastępczej nie powielali niewłaściwych postaw wyniesionych z domu rodzinnego. Uważam, że tematyka dotycząca procesu usamodzielnienia jest niezwykle ważnym obszarem zagadnień naukowych, gdyż kształtuje przyszłe samodzielne pokolenie młodych ludzi, którzy rozpoczynają dorosłe życie przy wsparciu odpowiednich grup instytucjonalnych. Usamodzielnienie wychowanka umieszczonego $\mathrm{w}$ rodzinie zastępczej wymaga odpowiedniego przygotowania osób pełniących funkcję rodziny zastępczej, a także stosownej wiedzy pracowników współpracujących i wspierających tę rodzinę w prawidłowym wypełnianiu jej funkcji. W artykule pragnę przedstawić problem usamodzielnienia wychowanka $\mathrm{w}$ aspekcie kształtowania postawy przedsiębiorczej w kontekście zasady subsydiarności, która stanowi jedną z podstawowych funkcji opieki społecznej.

Dotychczasowe wyniki badań nad funkcjonowaniem opieki zastępczej w Polsce skłoniły mnie do podjęcia problematyki losów wychowanków z rodzin zastępczych u progu ich dorosłości. Dostępna literatura przedmiotu ukazuje różnorodne informacje o rodzinach zastępczych, ich prawach i obowiązkach, regulacjach prawnych, formach wsparcia. Badania przeprowadzone przez pedagogów obejmują głównie opis funkcjonowania rodzin zastępczych w środowisku miejskim, z pominięciem środowisk wiejskich (Ruszkowska, 2013). Materiały prasowe stały się inspiracją do naszkicowania portretu pieczy zastępczej przez Martę Danecką i Jacka Cieślara (Danecka, Cieślar, 2016). Autorzy poddali analizie artykuły prasowe zamieszczone w czasopismach "Gazeta Wyborcza”, „Rzeczpospolita”, „Do rzeczy”, ,W sieci” oraz „Polityka” w latach 2010-2015. Jak wynika z eksplikacji poszczególnych tekstów, problematykę rodzin zastępczych ukazywano głównie w świetle pejoratywnym. Wyartykułowano przede wszystkim patologiczne zachowania, przestępstwa w rodzinach zastępczych oraz błędy w prawidłowym realizowaniu pieczy zastępczej. Uogólniając można stwierdzić, że tematyka dotyczyła opisu funkcjonowania rodzin zastępczych w Polsce, regulacji prawnych, omówienia założeń nowej ustawy oraz jej nowelizacji (Danecka, Cieślar, 2016).

Problem opieki zastępczej był i jest nadal przedmiotem badań naukowych, zwłaszcza w obszarze nauk społecznych. Jednakże wydaje się, że dostępna literatura nie jest wystarczająca. Usamodzielnienie wychowanków w rodzinach zastępczych, ich losy w dorosłym życiu są zagadnieniem wymagającym dalszych badań, zarówno w obszarze pedagogicznym, jak i socjologicznym czy prawnym.

\section{Charakterystyka rodzinnej i instytucjonalnej rodziny zastępczej}

Funkcjonowanie rodzin zastępczych oraz instytucjonalnych placówek opiekuńczo-wychowawczych w Polsce reguluje Ustawa o wspieraniu rodziny i systemie 
pieczy zastępczej (Dz.U. $2011 \mathrm{nr} 149$ poz. 887). Nowe przepisy wynikające z tej ustawy zmieniają regulacje, które obowiązywały na podstawie Ustawy o pomocy społecznej (Dz.U. $2004 \mathrm{nr} 64$ poz. 593). Obowiązki związane z pracą z rodzinami w oparciu o nową ustawę należą do zadań gmin oraz powiatów. Wiąże się to zatem $\mathrm{z}$ zatrudnieniem $\mathrm{w}$ gminach asystentów rodziny, których zadaniem jest pomoc rodzinom w realizacji funkcji opiekuńczo-wychowawczych, natomiast do zadań powiatu należy wyłonienie organizatora rodzinnej pieczy zastępczej, który zatrudnia koordynatora rodzinnej pieczy zastępczej, działającego na rzecz wsparcia rodzin zastępczych.

W myśl obowiązującej ustawy system pieczy zastępczej zostaje rozpoczęty w sytuacji, gdy rodzina biologiczna funkcjonuje w nieprawidłowy sposób bądź w przypadku niemożności zapewnienia wychowania dziecka przez rodziców (półsieroctwo, sieroctwo). Umieszczenie dziecka w pieczy zastępczej następuje na podstawie orzeczenia sądu. Piecza zastępcza w założeniu ma charakter czasowy, jednakże większość dzieci umieszczonych w placówce lub rodzinie zastępczej pozostaje $\mathrm{w}$ niej do osiągnięcia pełnoletniości lub do czasu ukończenia nauki. Osoby sprawujące pieczę nad dzieckiem zobowiązane są do zapewnienia właściwej opieki, godnego, samodzielnego życia, nawiązywania i podtrzymywania kontaktów z rodzicami biologicznymi, rówieśnikami, a także do zapewnienia potrzeb emocjonalnych w celu łagodzenia skutków doświadczenia separacji lub też straty (Ustawa..., art. 32-33). Jednakże istotnym zadaniem jest przygotowanie wychowanka do samodzielnego życia w społeczeństwie (Dubis, 2015), a co za tym idzie - kształtowania postaw przedsiębiorczych w celu pokonywania trudności życiowych. Obowiązujący system pieczy zastępczej w Polsce przedstawiono na rys. 1 .

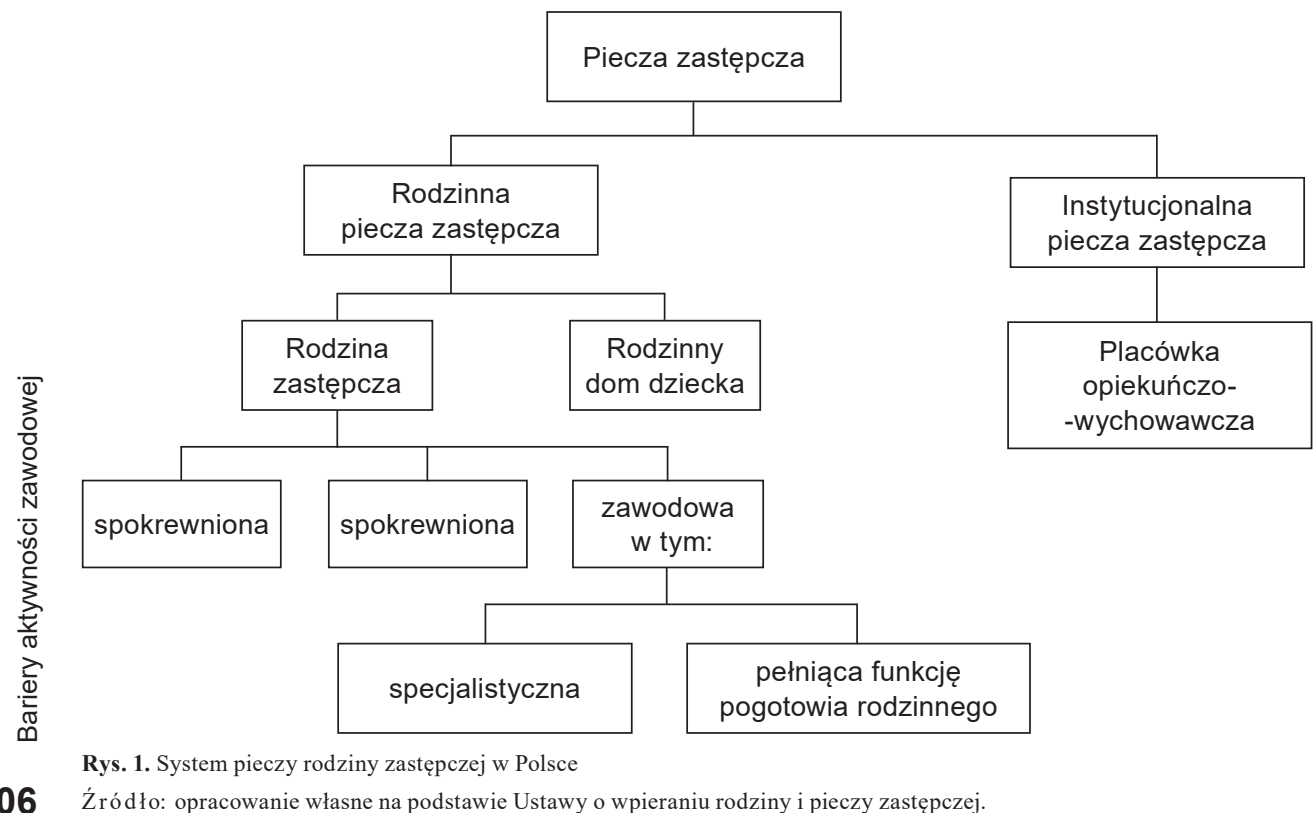

Źródło: opracowanie własne na podstawie Ustawy o wpieraniu rodziny i pieczy zastępczej. 
Ustawa ujmuje w kategoriach formalnych proces usamodzielnienia wychowanka w pieczy zastępczej. Związany jest on z ostatnim etapem pobytu w placówce opiekuńczo-wychowawczej lub rodzinie zastępczej. Jednakże proces usamodzielnienia nie może ograniczać się tylko do ram czasowych związanych z pełnoletniością wychowanka. W świetle zapisów obowiązującej ustawy wychowankowie opuszczający rodziny zastępcze powinny uzyskać środowiskowe wsparcie. Jak wynika z praktyki, otrzymanie takiej pomocy wymaga szerokiej współpracy pomiędzy instytucjami, organizacjami, tymczasem obecnie sprowadza się to do formalnej pomocy pełnoletniemu wychowankowi. Brakuje kompleksowej, wszechstronnej pomocy w usamodzielnianiu się młodego człowieka z uwzględnieniem jego indywidualnych możliwości, umiejętności, potrzeb (Kowalski, Dubis, red., 2015).

\section{Istota zasady subsydiarności w ujęciu społecznym}

Geneza idei pomocniczości sięga czasów starożytnych. W społeczeństwie opisanym przez Arystotelesa ideę pomocniczości przyjmowano jako pewną oczywistość, która polegała na potrzebie przynależności grup mniejszych do grup większych, a ich celem była realizacja niektórych zadań społecznych. Według myśli Arystotelesa, zadania poszczególnych grup nakładają się na siebie. Idea pomocniczości nie jest oparta na brakach, deficytach, niewystarczalności poszczególnych jednostek lub grup społecznych, lecz jej celem jest rozwój i doskonalenie się społeczeństwa (Millon-Delsol, 1995, s. 11-12).

Nauka społeczna Kościoła odegrała niewątpliwie istotną rolę w rozwoju ustrojów demokratycznych państw europejskich. Zajmowała się kwestiami społecznymi, które były obecne w Kościele od samego początku. Oficjalne dokumenty Kościoła odpowiadały na niektóre problemy społeczne, poruszały kwestie dotyczące relacji państwo-obywatel (Grzegorski, 2012).

Papież Leon XIII 15 maja 1891 roku ogłosił encyklikę Rerum novarum (o kwestii robotniczej), która dała początek i podstawy katolickiej nauce społecznej. Papież podjął się próby odpowiedzi na główne pytania społeczne, przedstawił w swojej encyklice zarys oraz analizę ówczesnej sytuacji społeczno-gospodarczej (Molendowska, 2011). Podkreśla, że ingerencja państwa w kwestie społeczne powinna być ograniczona: „Prawo wymaga, żeby ani jednostka, ani rodzina nie była pochłaniana przez państwo; jest więc rzeczą słuszną, by i jednostka, i rodzina miała swobodę działania, jak długo nie zagraża dobru powszechnemu lub nie wyrządza krzywdy bliźniemu" (Le on XIII, 2005 [1891], s. 28-29). Autor zakłada również, że są pewne sytuacje, w których państwo, władza świecka, może, a wręcz powinna interweniować, zapewniając ochronę praw obywatelskich, a także chroniąc poszanowania godności osoby ludzkiej: „Jeśli zatem interesy bądź ogółu, bądź jednej klasy społecznej zostały naruszone lub zagrożone, a nie ma już innych środków zaradczych, wówczas należy uciec się do władzy publicznej”. Dalej papież 
podkreśla, że rola pomocnicza państwa musi być ograniczona: „Chcieć więc, żeby władza świecka przenikała swym rządem aż do wnętrza domu, jest błędem wielkim i zgubnym. $Z$ pewnością jeśli jakaś rodzina znajdzie się $w$ wielkich trudnościach i bez rady, że sama się z nich wyzwolić nie może, jest rzeczą słuszną, by jej w tych ostatecznościach państwo udzieliło pomocy; rodziny bowiem są cząstkami państwa. Tak samo, kiedy w obrębie czterech ścian domu przyjdzie do poważnego podeptania praw wzajemnych, niech wówczas władza państwowa odda każdemu, co mu się należy; będzie to nie pochłanianie praw obywatelskich, ale ich obrona i wykonywanie słusznej, a powinnej opieki” (Le o n XIII, 2005 [1891], s. 29).

Ponadto papież kładł nacisk na to, aby państwo angażowało się w rzeczywistość społeczną z zachowaniem wielkiej ostrożności. Ingerencja władzy publicznej powinna być obwarowana pewnymi ustalonymi granicami. Papież Leon XIII wyznaczył obszary, w których państwo jest zobowiązane podejmować działanie, są to między innymi: zatrudnienie, warunki pracy, wynagrodzenie, ochrona własności prywatnej, a także ochrona kobiet i dzieci (Molend owska, 2011).

Słowo „pomocniczość” zostało zdefiniowane w 1931 roku w encyklice Quadragesimo anno papieża Piusa XI, wydanej w 40. rocznicę ogłoszenia encykliki Rerum novarum. Następca kontynuował zagadnienia społeczne związane z zasadą subsydiarności. Papież Pius XI mówi o istocie zasady pomocniczości, która tkwi w elastycznym sposobie, metodach reagowania podmiotów wyższych na podmioty na szczeblach niższych (Bąkows ki, 2007). Encyklika Quadragesimo anno stawia zasadę subsydiarności jako najwyższe prawo w filozofii społecznej (Pius XI, 2002 [1931]). Podkreśla, że ingerencja państwa w życie społeczne jednostek, grup społecznych powinna występować tylko wówczas, gdy jest to konieczne (Molendowska, 2011). W traktacie o Unii Europejskiej w 1992 roku przyjęto także jako ogólnie obowiązującą zasadę pomocniczości, która stosowana była w odniesieniu do polityki ochrony środowiska w Jednolitym akcie europejskim. Zasada ta ustala granicę ingerencji Unii Europejskiej w poszczególnych krajach członkowskich, w obszarach, które nie należą do jej kompetencji wyłącznej, ,wspólnota podejmuje działania tylko wówczas, jeśli cele mogą być lepiej zrealizowane na poziomie wspólnotowym niż krajowym" (Popławska, 2000, s. 8).

„Subsydiarność" (łac. subsydium — pomoc, wsparcie) opiera się na zasadach, których praktyczny wymiar można przedstawić następująco. Wyżej zorganizowana grupa społeczna powinna nieść pomoc grupom na niższych szczeblach, z kolei jednostki niższe powinny zgłosić się o pomoc do wyższych grup. Należy także określić kryteria i granice udzielanej pomocy, by nie pojawiło się uzależnienie. Jednym z założeń pomocy społecznej jest reguła pomocniczości, rozumiana jako zapobieganie, wspieranie jednostek, grup społecznych w wszelkich działaniach zmierzających do zaspokojenia niezbędnych potrzeb, a także umożliwienie funkcjonowania w godnych warunkach. Subsydiarność zakłada, że państwo, organy pomocy społecznej powinny interweniować tylko wówczas, gdy jednostki, rodzina nie są w stanie samodzielnie wypełnić ról społecznych. Celem instytucji społecznych jest zatem aktywizacja podmiotów, które z powodu różnorodnych 108 dysfunkcji potrzebują wsparcia i fachowej pomocy. Zadaniem pomocy społecznej 
jest udzielenie należytego wsparcia, świadczeń, na tyle, na ile to konieczne, by pomoc instytucjonalna nie wyręczała w sposób trwały jednostek, grup, rodzin w realizowaniu ról społecznych (Mol1, 2014).

Pomoc społeczna w świetle zasady subsydiarności spełnia trzy funkcje:

1. Zapobiegawczą, występującą w trudnej sytuacji życiowej poszczególnych jednostek lub rodzin, w przypadku gdy trudności tych nie są w stanie samodzielnie pokonać pomimo posiadanych umiejętności, zasobów.

2. Gwarancyjną, polegającą na zapewnieniu minimalnej gwarancji dla strefy bytowej osób potrzebujących pomocy, co pozwala przetrwać im trudną sytuację życiową w warunkach odpowiadających godności istoty ludzkiej.

3. Aktywizacyjną, której istotą jest podejmowanie działań na rzecz aktywizacji podmiotów korzystających ze świadczeń pomocy społecznej, co ma na celu usamodzielnienia się życiowe jednostek, rodzin, a także zapewnienie integracji społecznej z środowiskiem lokalnym (Mo11, 2014).

Specyfikę przedsiębiorczości społecznej podkreśla Mirosław Grewiński: „[...] przedsiębiorczość to nie tylko postawa i działalność ekonomiczna, ale także społeczna, która realnie przyczyniać się może do zwiększania dobrobytu społecznego i społecznej szczęśliwości wielu grup zagrożonych wykluczeniem społecznym. Działania podmiotów gospodarki społecznej to praktyczne dowody i jednocześnie argumenty, które wpisują się w trwającą dyskusję i poszukiwanie najbardziej adekwatnej definicji i roli dla przedsiębiorczości społecznej, co wydaje się [...] zamierzeniem trudnym, a jednocześnie niezbędnym ze względu na znaczenie tego zjawiska dla rozwoju współczesnych społeczeństw, borykających się z wieloma problemami społecznymi” (Grewiński, 2012, s. 21).

Zasada subsydiarności występuje jako istotny element pracy z młodzieżą, zwłaszcza takiej grupy osób, która korzysta z instytucjonalnej pomocy społecznej. Zadaniem pracowników, którzy towarzyszą, wspierają młodych na progu dorosłego życia, jest motywowanie do podejmowania działań ukierunkowanych na przedsiębiorcze usamodzielnienie się. Pomoc materialna dla osób w trudnej sytuacji życiowej powinna być uwarunkowana sytuacyjnie i czasowo. Zasada pomocniczości zakłada wsparcie na tyle, na ile to konieczne, by nie uzależniać ludzi od otrzymywanego wsparcia, ale nakłaniać do podejmowania takich działań, które pomogą samodzielnie kroczyć przez życie.

Kształtowanie postaw przedsiębiorczych wymaga wiele wysiłku i pracy. Jednak uważam, że warto podjąć się tego wyzwania, zwłaszcza w grupie osób znajdujących się $\mathrm{w}$ trudnych sytuacjach życiowych, by mogły nabyć umiejętności wykorzystywania pojawiających się szans. Aktywizowanie młodzieży do podejmowania różnorodnych przedsiębiorczych działań może bowiem zachęcić ją do samodzielnego i kreatywnego myślenia, a także przeciwdziałać wykluczeniu społecznemu. 


\section{Postawy przedsiębiorcze wśród młodzieży - charakterystyka}

Przedsiębiorczość jest pojęciem o szerokim, wielowymiarowym znaczeniu. Można podjąć próbę wyjaśnienia i opisu tego terminu w ramach różnorodnych dziedzin nauki, tj. ekonomii, socjologii, psychologii. Zwykle pojęcie przedsiębiorczości wiąże się z prowadzeniem działalności gospodarczej, jednak nie jest to atrybut zarezerwowany wyłącznie dla osób prowadzących biznes. Przedsiębiorczość łączy się z jedną z cech podmiotowości człowieka, którą można określić jako zaradność życiową, elastyczne reagowanie na zachodzące zmiany w otoczeniu. Człowiek przedsiębiorczy charakteryzuje się pozytywnym myśleniem, dąży do osiągania coraz lepszych rezultatów, jest również zmotywowany do pracy (Piotrowski, 2012). Chciałabym podjąć próbę zarysowania problematyki kształtowania postaw przedsiębiorczych wśród młodzieży w świetle zasady subsydiarności, inaczej zwanej zasadą pomocniczości. Młodzi wychowankowie, którzy są umieszczeni w rodzinach zastępczych, uczestniczą w procesie usamodzielniania się, formalnie inicjowanym na rok przed osiągnięciem pełnoletniości (Ustawa..., art. 145). Czas procesu usamodzielniania się ma przygotować wychowanka na wkroczenie w samodzielne dorosłe życie, zdobycie wykształcenia, zawodu. Jednakże wielu młodych wychowanków nie potrafi samodzielnie rozpocząć życia społecznego, zawodowego, uciekając tym samym pod opiekę pomocy społecznej.

Zachodzące zmiany w otoczeniu, rozwój technologiczny wymagają od człowieka konieczności ciągłego przystosowywania się, a także poszukiwania nowych metod, sposobów działania, rozwiązywania problemów. Przedsiębiorczość w takim ujęciu to działanie zorientowane na aktywność i rozwój, tworzenie elastycznych struktur, promowanie innowacyjnych rozwiązań oraz samodzielności (Piotrowsk i, 2012). Człowiek przedsiębiorczy uzewnętrznia swoją cechę w działaniu, którego początkiem jest inicjatywa. Cecha ta pozwala jednostce działać, podejmować życiowe decyzje w sposób twórczy i innowacyjny. Osobę przedsiębiorczą wyróżnia wytrwałość i pewna nieustępliwość w dążeniu do celu. Ma ona wykształcenie pozwalające na ten typ aktywności, potrafi korzystać ze zdobytej wiedzy, możliwości obecnej technologii, a także z środków masowego przekazu (Piotrowski, 2012). Wielość definicji przedsiębiorczości pozwala na wyodrębnienie jednego wspólnego aspektu, jakim są cechy osobowości człowieka, które można podzielić na cechy wrodzone (inteligencja, odwaga, energia) oraz nabyte (wiedza, umiejętność negocjacji) (Piotrowski, 2012). Wyróżnia się także cechy osobowościowe, wśród których najczęściej wymieniane są: zapobiegliwość, zaradność, dynamiczność, pracowitość, wytrwałość, samodzielność, umiejętność wykorzystywania pojawiających się szans. Ich przeciwieństwem są: bezradność, bierność, lenistwo, pasywność, zaniedbania (Bieniak, 2007). Henryk Bieniak zaproponował tezę, że przedsiębiorczość osobista jest funkcją kilku czynników, przedstawiających się w następującej formie: 


$$
\mathrm{PO}=\mathrm{F}(\mathrm{G}, \mathrm{IQ}, \mathrm{IE}, \mathrm{W}, \mathrm{M})
$$

Oznaczenia tych czynników są następujące: pierwszym z nich są geny (G), dziedziczność pewnych cech, predyspozycji; kolejnymi są inteligencja ogólna (IQ) oraz inteligencja emocjonalna (IE); następnym elementem jest wiedza i wykształcenie (W), a także chęć ciągłego rozwoju i podnoszenia kwalifikacji zawodowych; zamyka tę funkcję motywacja (M), rozumiana jako początek wszelkiego działania, w oparciu o posiadany potencjał (Bieniak, 2007, s. 225-226). Kształtowanie postaw przedsiębiorczych wśród młodych ludzi powinno się zatem skupiać na umiejętności rozwiązywania problemów, twórczym myśleniu, a także otwartości na wszelki rodzaj nowości i innowacyjności. Szkoła jest miejscem, w którym można aranżować sytuacje, dające młodemu człowiekowi szanse podejmowania samodzielnych decyzji, mających wpływ na organizację szkoły, działalności społecznej (np. aktywny udział w samorządzie szkolnym, klasowym, udział w konkursach, projektach). Nauka przedsiębiorczości na etapie szkolnym daje możliwość kształtowania i rozwijania cech przedsiębiorczych wśród młodych ludzi. Uczniowie dzięki pracy indywidualnej, a także pracy w grupach mają szansę modelować, formować swoje umiejętności przedsiębiorcze. Autor podaje pewien schemat pracy dla młodego człowieka, zawierający się w skróconej formie $4 \mathrm{x} \mathrm{E}$ :

E - ekonomicznie,

E - estetycznie,

E- etycznie,

E - ekspresyjnie (Piotrowski, 2012, s. 96-103).

Osobowość człowieka przedsiębiorczego jest niewątpliwie jednym z czynników wpływających na działania przedsiębiorcze. Określa sposób zachowania, rozumiany jako ogół reakcji zachodzących pod wpływem bodźców wewnętrznych oraz zewnętrznych. Doświadczenie człowieka również decyduje o podejmowaniu różnorodnych decyzji. Dopełnieniem tego jest posiadana wiedza oraz umiejętności osoby (Kurek, 2001). Tadeusz Kotarbiński pojęcie przedsiębiorczości osobistej identyfikuje przez pryzmat osoby cechującej się inicjatywą, pełnej energii oraz aktywności, osoby, która w sposób energiczny podejmuje różnorodne zamierzenia. Osoba przedsiębiorcza w sposób twórczy inicjuje nowe przedsięwzięcia, bez zewnętrznych nakazów czy presji (Bieniak, 2007). Źródłem postawy przedsiębiorczej jest niewątpliwie środowisko wychowawcze, w którym człowiek dorasta, a także przekazywany system wartości. Zatem jednym z głównych zadań wychowawczych jest skłonienie młodego człowieka do wyznaczania sobie celów, świadomego planowania czasu, pozytywnego myślenia, kształtowania wysokiej motywacji, a także samooceny oraz wiary w swoje możliwości i umiejętności (Bieniak, 2007). 


\section{Analiza badań}

Przedmiotem podjętych badań empirycznych są problemy, z którymi borykają się wychowankowie przebywający w rodzinach zastępczych. Badanie miało na celu określenie poziomu wiedzy wychowanków na temat usamodzielnienia oraz dokonanie oceny rozwoju ich postawy przedsiębiorczej, a zwłaszcza ustalenie poziomu przygotowania młodego człowieka do samodzielnego życia. Ogólnie nakreślone cele badawcze tworzą pola problemowe, które wymagają odpowiedniego doprecyzowania przez postawienie pytań badawczych. Sformułowałam dwa główne problemy badawcze, w ramach których respondenci zostali zapytani o ocenę swojego przygotowania do samodzielnego życia, następnie ocenili poziom własnej postawy przedsiębiorczej.

Badaniem została objęta młodzież wychowująca się w rodzinach zastępczych oraz pochodząca z rodzin korzystających $w$ różnorodny sposób z pomocy społecznej na terenie województwa śląskiego. Grupa badawcza składała się z 90 osób, w tym 44 dziewcząt oraz 46 chłopców w wieku 15-19 lat. Badania przeprowadzono na podstawie kwestionariusza ankiety w 2017 roku.

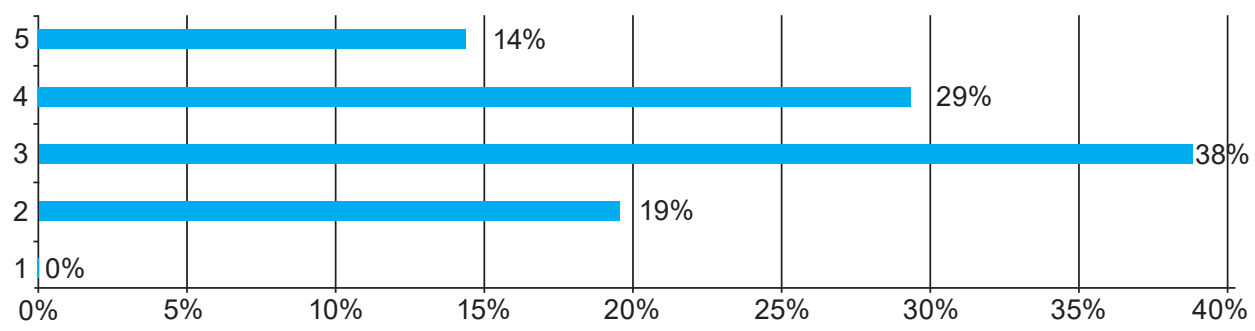

Wykres 1. Jak oceniasz swoje przygotowanie do samodzielnego życia?

Legenda: 1 - poziom bardzo zły, 2 - poziom zły, 3 - poziom średni, 4 - poziom dobry, 5 - poziom bardzo dobry

Źródło: badania własne

Przygotowanie do samodzielnego życia zostało ocenione przez młodzież na poziomie średnim (38\%) oraz dobrym (29\%). 19\% respondentów twierdzi, że ich przygotowanie do samodzielności w życiu dorosłym jest złe, a 14\% badanych uznało, że ich przygotowanie jest na poziomie bardzo dobrym. Usamodzielnienie jest końcowym etapem wychowywania się w rodzinie zastępczej, stanowi bowiem wyjście z tej rodziny. Proces usamodzielnienia ma doprowadzić osoby, wobec których świadczona jest wszechstronna pomoc, do ich życiowego usamodzielnienia i integracji ze środowiskiem. Zarówno funkcjonowanie dziecka w rodzinie zastępczej, jak i moment jej opuszczenia jest dla wychowanka trudnym przeżyciem.

Badani ocenili swoją postawę przedsiębiorczą na poziomie średnim (42\%) oraz dobrym (28\%). Źle ocenia postawę przedsiębiorczą $21 \%$ ankietowanych, bardzo źle $1 \%$, a bardzo dobrze $8 \%$. Można zauważyć, że badana młodzież na podobnym poziomie oceniła swoją postawę przedsiębiorczą i rozwój swoich umiejętności społecznych. 


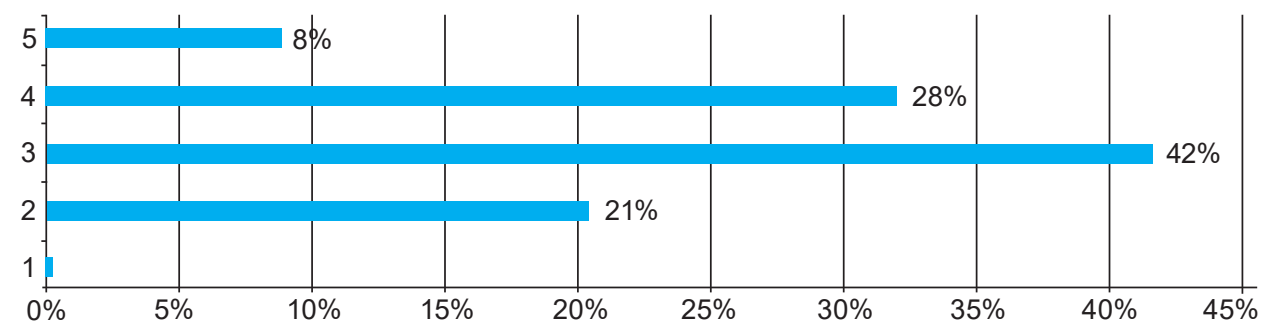

Wykres 2. Jak oceniasz swoją postawę przedsiębiorczą?

Legenda: 1 - ocena bardzo zła, 2 - ocena zła, 3 - ocena średnia, 4 - ocena dobra, 5 - ocena bardzo dobra

Źródło: badania własne

Respondenci ocenili swoją postawę przedsiębiorczą na poziomie średnim (42\%) i niemal na tym samym poziomie ocenili swoje przygotowanie do samodzielnego życia (38\%). Negatywna ocena może wynikać z wieku badanej młodzieży, wkraczającej w tym czasie w dorosłość. Wychowankowie rodzin zastępczych otrzymują pomoc materialną $\mathrm{w}$ trakcie procesu usamodzielnienia się na podstawie Indywidualnego Programu Usamodzielnienia, w którym wyznaczają sobie zadania, jakie chcą, a także mają możliwość zrealizować. Zadaniem pracownika pomocy społecznej jest wspomaganie i motywowanie wychowanków na drodze usamodzielniania się.

Przedsiębiorczość jako umiejętność elastycznego reagowania na zachodzące zmiany w otoczeniu jest ogromnym wyzwaniem zarówno dla rodziny zastępczej, jak i dla pracowników socjalnych. Wypracowanie tej umiejętności przez młodych wychowanków pomoże im wkroczyć w dorosłość. Kształtowanie postaw przedsiębiorczych wśród młodych ludzi powinno skupiać się zatem na umiejętności rozwiązywania problemów. Wychowankowie rodzin zastępczych są bowiem narażeni na powielanie negatywnych cech i zachowań, których doświadczyli w domu rodzinnym. Kształtowanie postawy przedsiębiorczej pozwoli uniknąć powielania negatywnych cech i zachowań, takich jak bezradność opiekuńczo-wychowawcza, materialna, których wychowankowie doświadczyli w domu rodzinnym.

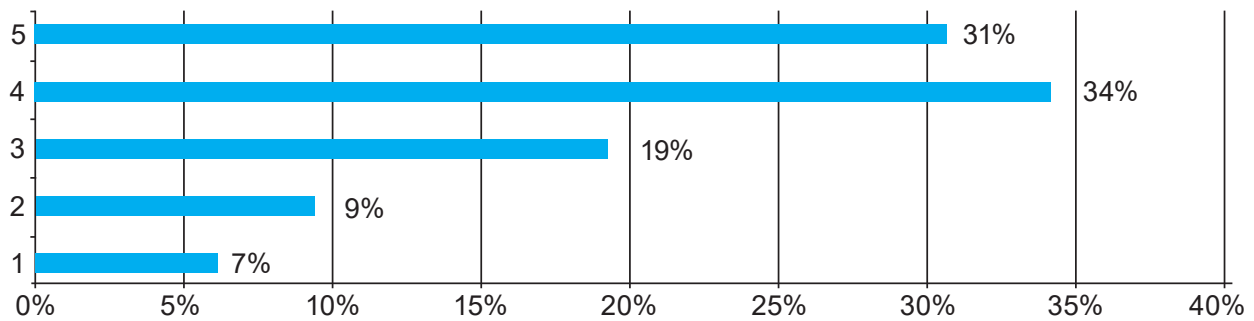

Wykres 3. Jak oceniasz swoje umiejętności zarządzania środkami finansowymi? Legenda: 1 - ocena bardzo zła, 2 - ocena zła, 3 - ocena średnia, 4 - ocena dobra, 5 - ocena bardzo dobra Źródło: badania własne 
Udzielając odpowiedzi na temat własnych umiejętności zarządzania środkami finansowymi, badani respondenci ocenili je dobrze (34\%), bardzo dobrze (31\%), średnio (19\%). Jedynie 9\% ankietowanych uznało, że ich umiejętności zarządzania finansami są złe, a 7\% — bardzo złe. Z uzyskanych odpowiedzi można wywnioskować, że młodzież dobrze ocenia swoją umiejętność zarządzania środkami materialnymi.

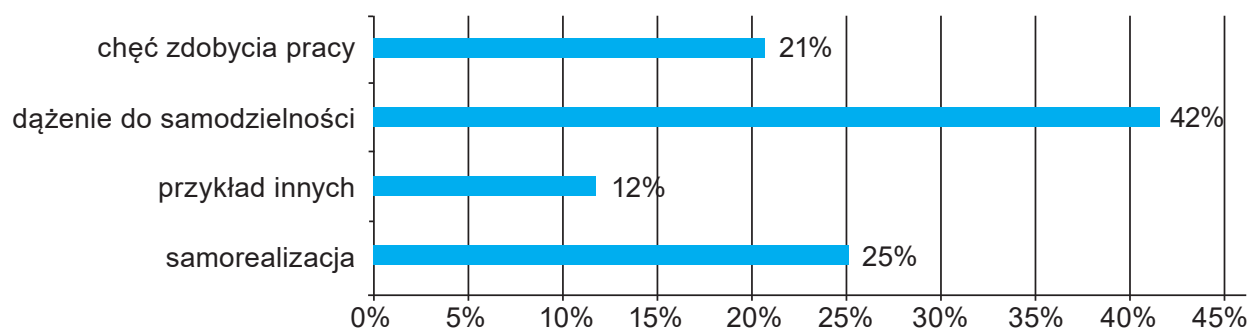

Wykres 4. Jakie są motywy podejmowania decyzji o usamodzielnieniu się?

Źródło: badania własne

Największą motywacją do podjęcia decyzji o usamodzielnieniu się jest w opinii grupy badawczej dążenie do samodzielności i niezależności (42\%). Ważnymi czynnikami mającymi znaczenie w procesie usamodzielnienia są także: samorealizacja (25\%) oraz chęć zdobycia pracy (21\%). Przykład innych osób (rodziny, znajomych) stanowi motywację dla $12 \%$ ankietowanych.

Decyzja o usamodzielnieniu się wiąże się z dążeniem do samodzielności, a więc też do pewnej niezależności i sprawczości w dorosłym życiu, co potwierdziło się w badaniu. Prawie połowa badanej młodzieży (42\%) uznała, że największą motywacją w podjęciu decyzji o usamodzielnianiu była wola indywidualnego, podmiotowego podejmowania decyzji. Takie zachowanie może wskazywać na autentyczną chęć dążenia do samodzielnego życia, bez korzystania z pomocy materialnej instytucji społecznych. Start w dorosłe życie stanowi poważne wyzwanie dla każdego młodego człowieka, a szczególnie trudne staje się dla osoby obciążonej bagażem życiowych doświadczeń. W przypadku wychowanków placówek proces usamodzielnienia wymaga nie tylko umiejętności radzenia sobie z codziennymi problemami, ograniczonymi finansami, czy też kłopotami mieszkaniowo-socjalnymi, ale także odbudowania własnej wartości oraz przyswojenia właściwych wzorców funkcjonowania rodziny.

Respondenci zostali zapytani o formę wsparcia, na którą mogą liczyć $\mathrm{w}$ trakcie procesu usamodzielniania. Za największe wsparcie badani respondenci uznali rodzinę (70\%), z kolei 17\% badanej młodzieży liczy na pomoc przyjaciół, znajomych. Natomiast 13\% ankietowanych uważa, że nie ma na kogo liczyć podczas usamodzielnienia. Nikt spośród młodzieży nie wybrał instytucjonalnego wsparcia.

Za niezwykle istotną kwestię w procesie wychowania dzieci i młodzieży oraz stwarzania im warunków do prawidłowego rozwoju uważa się kształtowanie 114 systemu wartości. Wypracowanie oraz ukształtowanie właściwej, trwałej hierarchii 


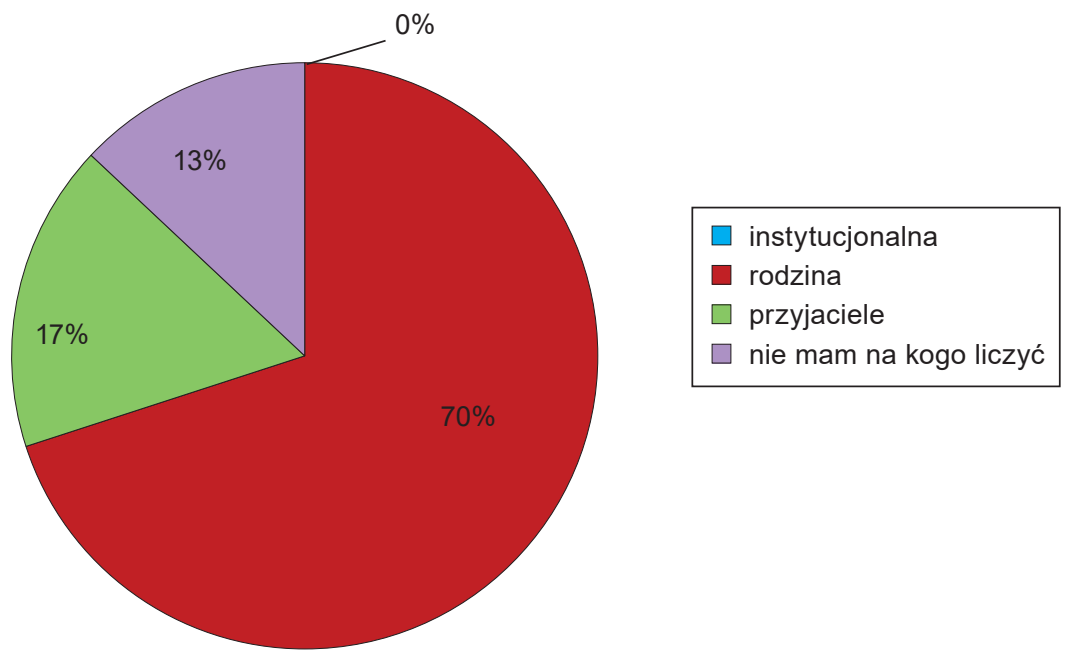

Wykres 5. Na jaką formę wsparcia możesz liczyć podczas procesu usamodzielnienia? Źródło: badania własne

wartości można uznać za czynnik niezbędny do świadomego życia, podejmowania odpowiedzialnych decyzji, dokonywania pewnych wyborów oraz przejawiania określonych zachowań.

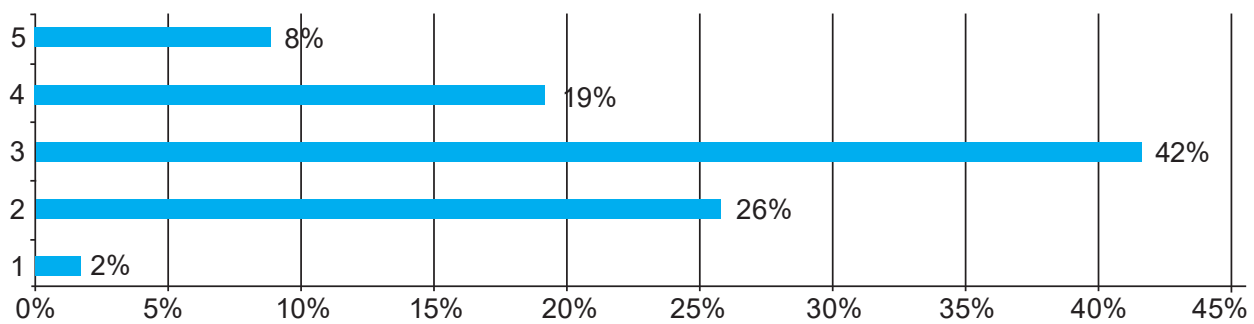

Wykres 6. Jak oceniasz wsparcie instytucji w procesie usamodzielnienia?

Legenda: 1 - ocena bardzo zła, 2 - ocena zła, 3 - ocena średnia, 4 - ocena dobra, 5 -ocena bardzo dobra

Źródło: badania własne

Respondenci zostali poproszeni również o ocenę wparcia instytucjonalnego $\mathrm{w}$ trakcie procesu usamodzielnienia. Prawie połowa grupy badawczej uznała, że ta forma wsparcia występuje na poziomie średnim, 26\% twierdzi, że pomoc instytucjonalna jest zła, $19 \%$ badanych oceniło wsparcie instytucji społecznych jako dobre, a $8 \%$ jako bardzo dobre. Jedynie $2 \%$ młodzieży uznało pomoc instytucjonalną za bardzo złą.

Na pytanie o wartości ponad $88 \%$ respondentów odpowiedziało, że najważniejszą wartością jest szczęście rodzinne. Pośród innych wartości największe znaczenie w życiu badanej młodzieży odgrywają: zdrowie (73\%), bezpieczeństwo (59\%) oraz trwałe przyjaźnie (56\%). Istotnymi wartościami w opinii grupy badawczej są także wartości związane z życiem zawodowym człowieka, m.in.: nieustanny rozwój przez 


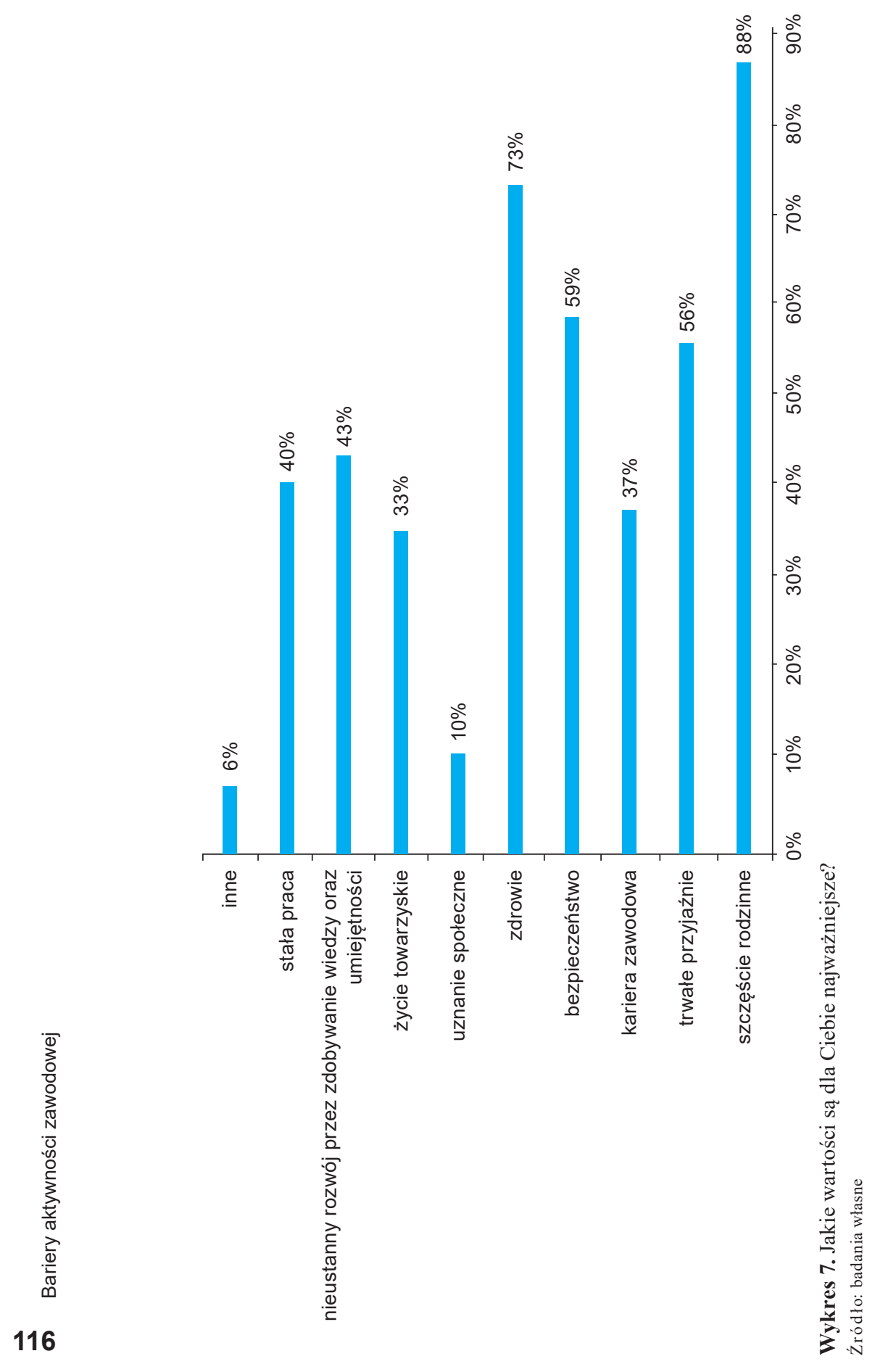


zdobywanie wiedzy oraz umiejętności (43\%), stała praca (40\%), kariera zawodowa, uznanie społeczne (10\%). Wśród innych odpowiedzi znalazły się takie formuły, jak: Bóg, wiara, honor, ojczyzna (6\%).

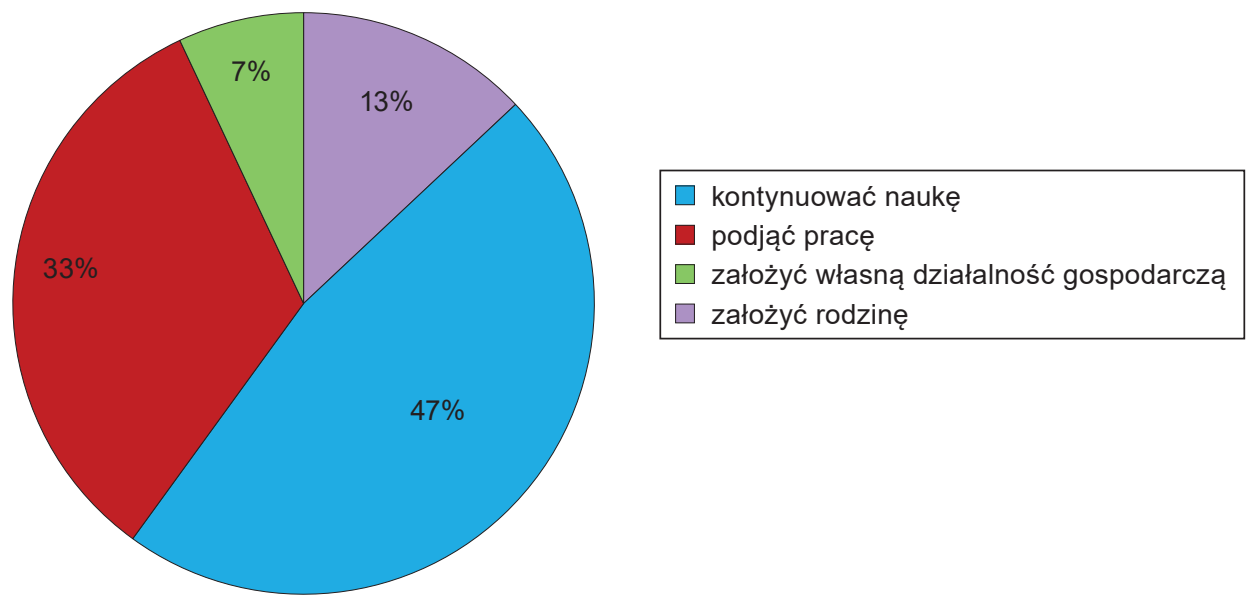

Wykres 8. Co chciałbyś robić po osiągnięciu dorosłości?

Źródło: badania własne

Prawie połowa badanych (47\%) uważa, że po osiągnięciu dorosłości warto kontynuować naukę, $33 \%$ wskazuje, że chce przede wszystkim podjąć pracę zawodową, $13 \%$ opowiada się za założeniem rodziny, a jedynie $7 \%$ optuje za założeniem własnej działalności gospodarczej. Przytoczone wyniki pokazują, że respondenci chcą kontynuować swoją ścieżkę edukacyjną bądź zawodową. Jednakże można zwrócić uwagę na bardzo niski wskaźnik dotyczący założenia rodziny. Być może wynika to z doznanych traumatycznych przeżyć z dzieciństwa, zmiany środowiska wychowawczego. Młodzież wcześniej zaznaczyła, że najważniejsze jest dla niej szczęście rodzinne i poczucie bezpieczeństwa. Sytuacja rodzinna, w jakiej się dorasta, kształtuje osobowość człowieka, a także znacząco wpływa na jego dalszy rozwój.

\section{Podsumowanie}

Samodzielność jednostki można potraktować jako jedną z naturalnych faz życia człowieka, a także powiązać ją ze zdolnością do podejmowania aktywności pozwalającej jednostce na samorealizację. Proces wkraczania w dorosłe życie wychowanka umieszczonego w rodzinie zastępczej z całą pewnością różni się od tego, będącego udziałem jednostki, która wyrastała w pełni funkcjonalnej własnej rodzinie biologicznej. Jedną z cech odmienności procesu usamodzielnienia się młodzieży wychowanej w rodzinach biologicznych i zastępczych są regulacje 
prawne i warunki instytucjonalne dotyczące wchodzenia w dorosłość. Jak wynika z przeprowadzonych analiz, badani respondenci w zasadzie nie liczą na wsparcie instytucjonalne, co może niepokoić jako czynnik składający się na obawy dotyczące narażenia wychowanków rodzin zastępczych na powielanie utrwalonych zachowań rodziców biologicznych, czyli zachowań wiążących się z bezradnością życiową w sprawach opiekuńczo-wychowawczych, jak też tych dotyczących uzależnienia od korzystania z pomocy społecznej. W tym kontekście warto podkreślić, że system rodzinnej pieczy zastępczej pełni istotną funkcję prospołeczną, a więc ma fundamentalne znaczenie w przekazywaniu przez rodziny zastępcze prawidłowych, podmiotowych postaw społecznych. Kształtowanie postawy przedsiębiorczej jest zatem niezwykle ważne, aby wychowanek mógł samodzielnie wkroczyć w dorosłe życie i zyskać w nim pełną podmiotowość.

Dodatkowo warto podkreślić, że niewątpliwie tematyka usamodzielniania się wychowanków rodzin zastępczych wymaga dalszych badań. Jest to bowiem ważna społecznie kwestia, która wiąże się z brakami przygotowania tej części młodzieży do wkroczenia w dorosłe życie oraz z jej znaczącymi trudnościami finansowymi, jak też z deficytami adresowanych do tej kategorii osób systemowych programów wsparcia.

\section{Bibliografia}

Bąkowski T., 2007: Administracyjnoprawna sytuacja jednostki w świetle zasady pomocniczości. Kraków: Wolters Kluwer.

Bieniak H., 2007: Ksztattowanie postaw przedsiębiorczych młodzieży w rodzinie, szkole i uczelni. W: P. Wachowiak, M. Dąbrowski, B. Majewski, red.: Kształtowanie postaw przedsiębiorczych a edukacja ekonomiczna. Warszawa: Fundacja Promocji i Akredytacji Kierunków Ekonomicznych, s. 225-232.

Danecka M., Cieślar J., 2016: Portret rodzin zastępczych — przekaz medialny a opinia społeczna. „Kultura i Społeczeństwo”, T. 60, nr 3, s. 133-149.

Dubis M., 2015: Proces usamodzielnienia w opinii wychowanków placówek socjalizacyjnych województwa lubelskiego. W: W. Kowalski, M. Dubis, red.: Piecza zastępcza: od wsparcia do usamodzielnienia. Lublin: Wyższa Szkoła Ekonomii i Innowacji w Lublinie.

Grewiński M., 2012: Gospodarka społeczna w UE $i$ w Polsce - między przedsiębiorczościa społeczna a CSR. W: Przedsiębiorczość - stan i perspektywy. Warszawa: WSP TWP, http://mirek.grewinski.pl/wp-content/uploads/2013/11/gospodarka-spoleczna-wue-i-w-polsce-miedzy-przedsiebiorczoscia-spoleczna-i-csr.pdf [dostęp: 21.12.2017].

Grzegorski S., 2012: Pojęcie i znaczenie zasady pomocniczości (subsydiarności) do realizacji zadań publicznych przez organizacje pozarzadowe w Polsce. Wrocław.

Kowalski W., Dubis M., red., 2015: Piecza zastępcza: od wsparcia do usamodzielnienia. Lublin. Wyższa Szkoła Ekonomii i Innowacji w Lublinie.

Kurek Z., 2001: Wprowadzenie w przedsiębiorczość. Olsztyn: OWSiZ. 
Leon XIII, 2005 [1891]: Encyklika Rerum novarum (o kwestii robotniczej). W: Encykliki społeczne Kościoła katolickiego. Świdnica: Wyższe Seminarium Duchowne Diecezji Swidnickiej, s. 16-29.

Millon-Delsol Ch., 1995: Zasada pomocniczości. Tłum. Cz. Porębski. Kraków: Znak.

Molendowska M., 2011: Ewolucja chrześcijańsko-demokratycznej wersji zasady pomocniczości. W: A. Pawłowska, S. Grabowska, red.: Zasada pomocniczości, wymiar europejski, narodowy, regionalny i lokalny. Rzeszów: Wydawnictwo Uniwersytetu Rzeszowskiego, s. 11-15.

Mol1 T., 2014: Zasada subsydiarności w świetle wybranych świadczeń pomocy społecznej. „Roczniki Administracji i Prawa”, nr 2.

Piotrowski K., 2012: Kształtowanie postaw przedsiębiorczych wśród młodych pracowników. W: P. Wrzecioniarz, red.: Nauczanie przedsiębiorczości na Dolnym Ślasku. Wrocław: Oficyna Wydawnicza Politechniki Wrocławskiej, s. 96-103.

Pius XI, 2002 [1931]: Encyklika Quadragesimo anno. O chrześcijańskim ustroju społecznym. Wydawnictwo Te Deum.

Popławska E., 2000: Zasada subsydiarności w traktatach z Maastricht i Amsterdamu. Warszawa.

Ruszkowska M., 2013: Diagnoza rodzin zastępczych w obliczu dylematów współczesności. Warszawa.

\section{Akty prawne}

Ustawa z dn. 9 czerwca 2011 o wspieraniu rodziny i systemie pieczy zastępczej. 